\title{
Senam Aerobik untuk Meningkatkan VO2 Max Mahasiswa Tingkat II Poltekkes Kemenkes Riau Prodi DIII Keperawatan di Luar Kampus Utama
}

\author{
Elmukhsinur \\ Prodi D3 Keperawatan Kab Inhu, Poltekkes Kemenkes Riau; elmukhsinurmanaf@ gmail.com (koresponden) \\ Yulianto \\ Prodi D3 Keperawatan Kab Inhu, Poltekkes Kemenkes Riau; Anto_dw3an@yahoo.co.id
}

\begin{abstract}
Sedentary lifestyle is one of the ten causes of death and disability in the world. More than two million deaths each year are caused by lack of movement or physical activity. The majority of teenagers are lazy to move and exercise. Aerobic exercise like aerobics is needed to achieve fitness. One way to assess fitness by measuring $\mathrm{VO}_{2}$ Max. This study aimed to look at the effect of aerobics on $\mathrm{VO}_{2}$ Max Level II students of the Poltekkes Kemenkes Riau Department of Nursing Education Study Program Outside the Main Campus. This research was an experimental research with one group pre-test-post test design approach. The samples size was 31 people, consisting of 22 women and 9 men. $\mathrm{VO}_{2}$ Max was tested using the Bleep test. Measurement of $\mathrm{VO}_{2} \mathrm{Max}_{\text {is }}$ done twice, namely before doing aerobic exercises and after doing aerobic exercises for 6 weeks with a frequency of 3 times a week, each aerobic exercise duration of 45 minutes. Data were analyzed by paired sample t-test. The results showed the average $\mathrm{VO}_{2}$ Max value of female students before and after doing aerobic exercise increased from $21.84 \mathrm{ml} / \mathrm{kg} /$ minute to $25.26 \mathrm{ml} / \mathrm{kg} /$ minute, with a p value of 0.000 . In male students there was also an increase in the average $\mathrm{VO}_{2}$ Max before and after aerobic exercise from $29.08 \mathrm{ml} / \mathrm{kg} / \mathrm{min}$ to $34.07 \mathrm{ml} / \mathrm{kg} /$ min with a $p$ value of 0.002. Based on the results of the study concluded, aerobic exercise affects the increase in $\mathrm{VO}_{2}$ Max Polytechnic students of the Ministry of Health Riau Study Program Outside the Main Campus.
\end{abstract}

Keywords: aerobics; exercise; $\mathrm{VO}_{2}$ Max; level II student

\begin{abstract}
ABSTRAK
Gaya hidup sedentary merupakan satu dari sepuluh penyebab kematian dan kecacatan di dunia. Lebih dari dua juta kematian setiap tahun disebabkan oleh kurangnya bergerak atau aktivitas fisik. Mayoritas remaja malas untuk bergerak dan berolahraga. Olahraga aerobik seperti senam aerobik diperlukan diperlukan untuk mencapai kebugaran. Salah satu cara menilai kebugaran dengan mengukur $\mathrm{VO}_{2}$ Max. Penelitian ini bertujuan untuk melihat pengaruh senam aerobik terhadap $\mathrm{VO}_{2}$ Max mahasiswa Tingkat II Poltekkes Kemenkes Riau Prodi DIII Keperawatan Di Luar Kampus Utama. Penelitian ini merupakan penelitian eksperimen dengan pendekatan One group pre test-post test design. Jumlah sampel sebanyak 31 orang, yang terdiri dari 22 perempuan dan 9 lakilaki. $\mathrm{VO}_{2} \mathrm{Max}$ di test dengan menggunakan Bleep test. Pengukuran $\mathrm{VO}_{2} \mathrm{Max}$ di lakukan sebanyak dua kali yaitu sebelum melakukan senam aerobik dan sesudah melakukan senam aerobik selama 6 minggu dengan frekuensi 3 kali seminggu, tiap senam aerobik berdurasi 45 menit. Data dianalisis dengan uji paired sample ttest. Hasil penelitian menunjukkan rata-rata nilai $\mathrm{VO}_{2}$ Max pada mahasiswa perempuan sebelum dan sesudah melakukan senam aerobik meningkat dari $21,84 \mathrm{ml} / \mathrm{kg} /$ menit menjadi 25,26 ml $/ \mathrm{kg} / \mathrm{menit}$, dengan nilai p 0,000 . Pada mahasiswa laki-laki juga terdapat peningkatan rata-rata $\mathrm{VO}_{2}$ Max sebelum dan sesudah senam aerobik dari $29,08 \mathrm{ml} / \mathrm{kg} / \mathrm{menit}$ menjadi $34,07 \mathrm{ml} / \mathrm{kg} / \mathrm{menit}$ dengan nilai $\mathrm{p} 0,002(<0,05)$. Berdasarkan hasil penelitian disimpulkan, senam aerobik berpengaruh terhadap peningkatan $\mathrm{VO}_{2} \mathrm{Max}$ mahasiswa Poltekkes Kemenkes Riau Program Studi di Luar Kampus Utama.
\end{abstract}

Kata kunci: senam aerobik; olahraga; $\mathrm{VO}_{2}$ Max; mahasiswa tingkat II

\section{PENDAHULUAN}

Olahraga sangat penting artinya bagi manusia karena dapat membina serta meningkatkan kebugaran jasmani (phisical fitness). Semua bentuk kegiatan manusia selalu memerlukan dukungan fisik /jasmani, sehingga masalah kemampuan fisik/jasmani merupakan faktor dasar bagi setiap aktifitas manusia. Oleh karena itu untuk setiap aktivitas kita sehari-hari, minimal kita harus mempunyai kemampuan fisik/jasmani yang selalu mampu mendukung tuntutan aktifitas itu dan tentu saja lebih baik lagi bila kita memiliki pula cadangannya. ${ }^{(1)}$

Saat ini banyak kita temukan orang malas untuk menggerakkan badannya sendiri, mereka terlalu dibuat nyaman oleh teknologi yang canggih namun membuat tubuh menjadi tidak sehat. Orang lebih banyak duduk santai di depan layar komputer. gaya hidup duduk terus-menerus (sedentary) akan berpotensi terhadap munculnya berbagai penyakit seperti penyakit jantung, diabetes mellitus dan hipertensi. Studi WHO menyatakan bahwa gaya hidup duduk terus-menerus dalam bekerja adalah 1 dari 10 penyebab kematian dan kecacatan di dunia. Lebih dari dua juta kematian setiap tahun disebabkan oleh kurangnya bergerak atau aktivitas fisik. ${ }^{(2)}$ 
Menurut American Cancer Society pada Juli 2010, terdapat 94 persen wanita dan 48 persen pria menghabiskan waktu dengan duduk atau tidak aktif selama 6 jam sehari memiliki risiko meninggal lebih cepat dari pada mereka yang aktif dan duduk kurang dari 3 jam sehari. ${ }^{(3)}$ Di Indonesia berdasarkan data Riset Kesehatan Dasar (Riskesdas) tahun 2018 sebanyak 33,5\% proporsi penduduk Indonesia masih tergolong memiliki gaya hidup kurang aktif. $^{(4)}$

Tubuh manusia di desain untuk selalu bergerak sehingga sangat dianjurkan untuk rajin berolahraga agar tercapai tingkat kebugaran yang diinginkan. Aktifitas olahraga yang dapat meningkatkan kebugaran jasmani adalah olahraga yang cukup memberikan baban kepada jantung dan paru. Jenis olahraga ini adalah olahraga yang sifatnya aerobik, diantaranya senam aerobik. ${ }^{(5)}$

Salah satu manfaat yag didapatkan dari senam aerobik adalah meningkatkan $\mathrm{VO}_{2}$ Max seseorang. $\mathrm{VO}_{2}$ Max adalah kemampuan organ pernafasan manusia untuk menghirup oksigen sebanyak-banyaknya pada saat latihan atau aktifitas fisik, sehingga nilai $\mathrm{VO}_{2} \mathrm{Max}$ biasanya digunakan sebagai indikator kebugaran seseorang. Fungsi atau kegunaan dari tes pengukuran $\mathrm{VO}_{2}$ Max adalah untuk mengetahui kebugaran jasmani seseorang, terutama untuk mengukur kemampuan daya tahan kardiorespirasi.

Secara fisiologis senam aerobik yang dilakukan sacara teratur dan terukur dapat memperbaiki sistem dan fungsi organ agar dapat menghasilkan kinerja yang lebih baik. Pada saat melakukan senam aerobik akan memacu atau merangsang kerja jantung, pembuluh darah dan paru. Keberhasilan mencapai kebugaran sangat ditentukan oleh kualitas latihan yang meliputi tujuan latihan, pemilihan model latihan, penggunaan sarana latihan dan yang lebih penting lagi adalah takaran atau dosis latihan seperti frekuensi, intensitas dan durasi latihan. Frekuensi menunjukkan jumlah latihan per minggu, intensitas menunjukkan seberapa berat badan bekerja atau latihan dilakukan, lama latihan menunjukkan waktu latihan yang digunakan.Untuk memperbaiki kebugaran lakukan senam aerobik 3-5 kali seminggu dengan lama latihan 20-30 menit, serta intensitas latihan $70-85 \%$ dari denyut nadi maksimal. ${ }^{(5)}$

Senam aerobik memiliki dampak yang positif terhadap kesehatan, terutama kemampuan jantung dan paru-paru. Penelitian yang dilakukan di Malang menemukan terdapat pengaruh yang bermakna senam aeobik terhadap daya tahan jantung paru dengan nilai $\mathrm{p}$ value $<0,001$. $^{(6)}$ Penelitian lain di tahun 2016 menyatakan terdapat perbedaan yang signifikan $\mathrm{VO}_{2}$ Max antara SMAN 1 Segeyan dengan SMAN 2 Ngaglik kabupaten sleman ${ }^{(7)} \mathrm{VO}_{2}$ Max siswa Segeyan lebih baik dari siswa Ngaglik, dengan nilai p 0,045(<0,05). ${ }^{(7)}$ Senam aerobic yang dilakukan selama 18 kali pertemuan atau 6 minggu terhadap siswa putri SMK Negeri 1 Surakarta, didapatkan hasil senam aerobik mix impact atau multi impact aerobik memberikan pengaruh yang signifikan dibandingkan senam aerobik low impact terhadap tingkat kebugaran jasmani. ${ }^{(8)}$

Tuntutan akan kebugaran jasmani setiap orang berbeda. Perbedaan ini biasanya dipengaruhi oleh jenis pekerjaan dari tiap-tiap orang. Untuk mahasiswa kebugaran jasmani diperlukan untuk belajar,kuliah dan kegiatan yang mendukung perkuliahan. Oleh karena itu setiap mahasiswa hendaknya memiliki kebugaran jasmani yang baik guna mendukung, mempermudah dan memperlancar perkuliahan. Terlebih bagi mahasiswa Poltekkes Kemenkes Riau program studi DIII Keperawatan Di Luar Kampus Utama, selain harus mengikuti perkuliahan teori dan praktek laboratorium yang padat, juga harus melaksanakan praktek klinik di rumah sakit.

Rutinitas kegiatan mahasiswa Poltekkes Kemenkes Riau program studi DIII Keperawatan di Luar Kampus Utama di mulai pukul 08.00 - 16.00. Dalam mengikuti proses belajar mengajar, sebagian mahasiswa tampak kurang bersemangat. Berdasarkan hasil observasi,setelah mengikuti kegiatan pembelajaran, mayoritas mahasiswa tidak ada melakukan olahraga. Berdasarkan latar belakang di atas peneliti ingin membuktikan pengaruh senam Aerobik terhadap kebugaran mahasiswa Tingkat II Poltekkes Kemenkes Riau program studi DIII Keperawatan di Luar Kampus Utama

\section{METODE}

Penelitian ini dilakukan di Prodi DIII Keperawatan Di Luar Kampus Utama pada tanggal 5 Agustus 2019 sampai dengan 17 September 2019. Jenis penelitian ini adalah penelitian eksperimen dengan pendekatan One group pre test-post test design, yaitu dengan melakukan pemeriksaan kebugaran jasmani $\left(\mathrm{VO}_{2}\right.$ max) pada satu kelompok saja tanpa kelompok pembanding. Senam aerobik dilakukan selama 6 minggu dengan frekuensi 3 kali seminggu, tiap senam dilakukan selama 45 menit, setelah responden melakukan pemanasan dahulu. Kegiatan senam ini dilakukan setelah aktivitas kuliah. Pengukuran kebugaran dilakukan sebelum dan sesudah perlakuan senam aerobik diberikan, dan pengaruh perlakuan senam aerobik diukur dari perbedaan antara pengukuran awal/pretest (O1) dan pengukuran akhir/post test (O2). Pre test dilakukan sebelum senam dilakukan dan post test dilakukan setelah 6 minggu perlakuan senam aerobic, responden istirahat 24 jam setelah kegiatan senam aerobic selesai sebelum dilakukan post test. Kebugaran di test menggunakan Bleep test dengan hasil ukur nilai $\mathrm{VO}_{2}$ Max. Data dianalisis dengan uji paired sample t-test. Sampel pada penelitian ini adalah 31 orang mahasiswa Poltekkes Kemenkes Riau Prodi DIII Keperawatan di Luar Kampus Utama yang memenuhi kriteria inklusi yaitu mahasiswa tingkat II, tidak sedang sakit, tidak mempunyai penyakit jantung, asma dan bersedia 
untuk mengikuti penelitian. Variabel dependen pada penelitian ini adalah tingkat kebugaran sedangkan variabel independen adalah senam aerobic.

\section{HASIL}

Dari penelitian ini maka didapatkan hasil sebagai berikut:

Tabel 1. Nilai $\mathrm{VO}_{2}$ Max mahasiswa sebelum dan sesudah senam aerobik

\begin{tabular}{|c|c|l|c|c|c|c|}
\hline No & Jenis kelamin & \multicolumn{1}{|c|}{ VO2 Max } & $\mathrm{n}$ & Mean & SD & P \\
\hline \multirow{2}{*}{1} & \multirow{2}{*}{ Perempuan } & Sebelum $(\mathrm{ml} / \mathrm{Kg} /$ menit) & 22 & 21,84 & 1,32 & \multirow{2}{*}{0,000} \\
\cline { 3 - 6 } & & Sesudah $(\mathrm{ml} / \mathrm{Kg} /$ menit) & 22 & 25,26 & 1,90 & \\
\hline \multirow{2}{*}{2} & \multirow{2}{*}{ Laki-laki } & Sebelum $(\mathrm{ml} / \mathrm{Kg} /$ menit $)$ & 9 & 29,08 & 2,86 & \multirow{2}{*}{0,002} \\
\cline { 3 - 6 } & & Sesudah $(\mathrm{ml} / \mathrm{Kg} /$ menit $)$ & 9 & 34,07 & 3,15 & \\
\hline
\end{tabular}

Tabel 1 menunjukkan rata-rata nilai $\mathrm{VO}_{2}$ Max mahasiswa perempuan mengalami peningkatan dari $21,84 \mathrm{ml} / \mathrm{Kg} /$ menit menjadi 25,26 ml/Kg/menit setelah melakukan senam aerobik selama 6 minggu, dengan nilai $\mathrm{p}$ Value 0,000. Berarti terdapat peningkatan $\mathrm{VO}_{2} \mathrm{Max}$ yang bermakna pada mahasiswa perempuan antara sebelum dan sesudah melakukan senam aerobik selama 6 minggu dengan frekuensi 3 kali seminggu, setiap senam berdurasi 45 menit. Sedangkan mahasiswa laki-laki terdapat peningkatan nilai rata-rata $\mathrm{VO}_{2} \mathrm{Max}_{\text {ada }}$ mahasiswa laki-laki dari $29,08 \mathrm{ml} / \mathrm{Kg} /$ menit menjadi $34,07 \mathrm{ml} / \mathrm{Kg} /$ menit setelah melakukan senam aerobik selama 6 minggu, dengan nilai p Value 0,002. Artinya terdapat peningkatan $\mathrm{VO}_{2} \mathrm{Max}$ yang bermakna pada mahasiswa laki-laki antara sebelum dan sesudah melakukan senam aerobik selama 6 minggu dengan frekuensi 3 kali seminggu, setiap senam berdurasi 45 menit.t

\section{PEMBAHASAN}

Perbedaan rata-rata $\mathrm{VO}_{2}$ Max sebelum dan sesudah perlakuan senam aerobik di uji dengan Paired Sample t-test . Pada penelitian ini didapatkan adanya peningkatan $\mathrm{VO}_{2}$ Max yang bermakna pada mahasiswa perempuan sebelum dan sesudah melakukan senam aerobik selama 6 minggu dengan frekuensi 3 kali seminggu, dengan nilai $\mathrm{p}$ 0,000. Begitu juga dengan mahasiswa laki-laki, juga terdapat peningkatan $\mathrm{VO}_{2} \mathrm{Max}$ yang bermakna antara sebelum dan sesudah melakukan senam aerobik, dengan nilai p 0,002. Rata-rata selisih $\mathrm{VO}_{2}$ Max pada mahasiswa laki-laki lebih tinggi dari pada perempuan, dimana pada mahasiswa laki-laki 4,98 dengan selisih minimal $\mathrm{VO}_{2}$ Max 0,30 dan selisih maksimal 11,30. Pada mahasiswa perempuan rata-rata selisih $\mathrm{VO}_{2}$ Max 3,40 dengan selisih minimal 0,40 dan selisih maksimal 7,10. Perbedaan $\mathrm{VO}_{2}$ max pada laki-laki dan perempuan dapat terjadi akibat perbedaan fisiologis. Laki-laki memiliki hormonal post pubertas yang menginduksi peningkatan konsentrasi $\mathrm{Hb}$ pada darah. Selain itu perempuan memiliki volume darah yang lebih sedikit dibandingkan dengan laki-laki sehingga berpengaruh terhadap perbedaan $\mathrm{VO}_{2}$ max keduanya. Perempuan memiliki kecenderungan penyimpanan lemak yang lebih tinggi dalam tubuh, kondisi ini menyebabkan penggunaan oksigen lebih banyak pada perempuan dibanding laki-laki ${ }^{(9)}$

Meskipun keduanya memiliki perbedaan dalam kapasitas $\mathrm{VO}_{2}$ Max. Kedua responden mahasiswa samasama mengalami peningkatan $\mathrm{VO}_{2}$ Max setelah aktivitas aerobic. Hal ini berarti senam aerobik yang dilakukan selama 6 minggu dengan frekuensi 3 kali seminggu, durasi tiap kali senam selama 45 menit berpengaruh terhadap tingkat kebugaran pada mahasiswa perempuan dan laki-laki. Penelitian ini mirip dengan penelitian yang dilakukan pada mahasiswa D IV Fisioterapi Poltekkes Surakarta, di dapatkan hasil senam aerobik selama 6 minggu dengan frekuensi 3 kali seminggu berpengaruh terhadap kelincahan mahasiswa perempuan dan lakilaki. Pada hasil uji statistik nilai kelincahan sebelum dan sesudah senam aerobic didapatkan nilai p 0,032 $(<0,05)$ pada laki-laki, dan pada wanita $0,003(<0,05) .{ }^{(10)}$ Penelitian lain juga menyatakan latihan fisik intensitas sedang berpengaruh terhadap kebugaran kardiorespirasi. Pada hasil penelitian didapatkan peningkatan nilai ratarata kebugaran respirasi secara signifikan sebelum perlakuan 32,74 menjadi 41,68 (p 0,000) setelah melakukan latihan fisik intensitas sedang dengan bersepeda statis selama 6 minggu, frekuensi 3 kali seminggu, setiap latihan selama 15 menit. $^{(11)}$

Keberhasilan pencapaian kebugaran paling penting ditentukan oleh takaran atau dosis latihan. Dosis latihan selalu terkait dengan intensitas, repetisi,frekuensi dan durasi latihan. Untuk mendapatkan hasil yang optimal,latihan aerobik dilakukan 3-5 kali seminggu, dengan intensitas 70-80 persen dari denyut nadi maksimal, durasi latihan 20-60 menit, dan juga yang sangat menentukan adalah lama latihan, beberapa minggu sampai beberapa bulan latihan aerobik di lakukan. Semakin lama waktu latihan di lakukan akan semakin baik untuk peningkatan kebugaran. ${ }^{(12)}$ 
Pada penelitian ini waktu atau lama senam aerobik yang dilakukan selama 6 minggu dengan frekuensi 3 kali seminggu, tiap senam berdurasi 45 menit. Jika di lihat dari frekuensi dan durasi senam aerobik yang dilakukan, sudah sesuai dengan takaran atau dosis latihan aerobik,tetapi lama latihan atau waktu senam aerobik yang dilakukan masih kurang lama, hanya 6 minggu. Semakin lama waktu senam aerobik dilakukan akan semakin baik untuk peningkatan kebugaran, jadi waktu atau lamanya senam aerobik yang dilakukan di anggap masih kurang, sehingga dianggap perlu untuk menambah waktu atau lamanya pelaksanaan senam aerobik.

$\mathrm{VO}_{2}$ Max atau daya tahan kardiorespirasi merupakan salah satu komponen kebugaran jasmani yang paling penting. Hidup seseorang bergantung pada kekuatan jantung, pembuluh darah, serta darah untuk mengantarkan nutrisi yang diperoleh dari proses pencernaan dan oksigen dari hasil respirasi untuk di sebarkan ke seluruh sel tubuh. Saat beraktivitas kenaikan frekuensi denyut jantung lebih lama dibandingkan dengan tidak beraktivitas. Pada orang yang terlatih setelah beraktivitas fisik, denyut jantung, pernapasan dan pembuluh darah akan lebih cepat kembali ke keadaan normal dari pada orang yang tidak terlatih. Efek akibat terciptanya peningkatan kebugaran fisik pada daya tahan kardiovaskuler yaitu terjadinya pembesaran otot jantung sehingga ukuran jantung meningkat, isi darah sekuncup perdenyut jantung bertambah sehingga volume yang dipompakan keseluruh tubuh lebih banyak, denyut jantung orang yang terlatih 6-8 kali lebih sedikit dari yang tidak terlatih dan peningkatan tekanan darah lebih sedikit.

Pada sistem respirasi pelatihan aerobik tidak merubah ukuran paru-paru tapi meningkatkan efisiensi pernapasan dengan cara meningkatkan kondisi otot-otot pernapasan dan mengurangi volume udara residu serta mengurangi frekuensi pernapasan untuk menggerakan volume udara yang sama. Selain itu pelatihan aerobik meningkatkan jumlah dan besar alveoli sehingga mempercepat suplai oksigen kedalam sel-sel tubuh. Hal ini menyebabkan peningkatan jumlah oksigen maksimal $\left(\mathrm{VO}_{2} \mathrm{Max}\right)$ yang dibutuhkan seseorang. Ini dapat tercapai jika seseorang mampu menghirup, menyalurkan dan menggunakan oksigen secara optimal. ${ }^{(11)}$

\section{KESIMPULAN}

Berdasarkan hasil penelitian didapatkan adanya peningkatan yang bermakna pada $\mathrm{VO}_{2}$ Max atau tingkat kebugaran mahasiswa Program studi DIII Keperawatan di Luar Kampus Utama Poltekkes Kemenkes Riau sebelum dan sesudah melakukan senam aerobik, sehingga dapat disimpulkan senam aerobik berpengaruh terhadap tingkat kebugaran mahasiswa Program studi DIII Keperawatan di Luar Kampus Utama Poltekkes Kemenkes Riau

Hasil penelitian ini membuktikan bahwa senam aerobik dapat meningkatkan tingkat kebugaran mahasiswa, sehingga kegiatan senam aerobik ini dapat di pertimbangkan menjadi program tetap di Program Studi DIII Keperawatan Di Luar Kampus Utama Poltekkes Kemenkes Riau, dengan mendatangkan instruktur senam yang tersertifikasi

\section{DAFTAR PUSTAKA}

1. Griwiyono S, Sidik D. Ilmu Faal Olahraga (Fisiologi Olahraga. Bandung: Remaja Rosdakarya; 2012.

2. Hasibuan R. Terapi Sederhana Menekan Gejala Penyakit Degeneratif. J Ilmu Keolahragaan. 2010;8(2):7893.

3. Prakoso A. Panduan dalam Hidp Sehat untuk Mencegah Penyakit Jantung dan Kematian Mendadak. Jakarta: Dinamika Media; 2011.

4. Kementrian Kesehatan Republik Indonesia. Riset Dasar Kesehatan. Jakarta; 2018.

5. Jonni. Senam Aerobik. Padang: Universitas Negeri Padang; 2011.

6. Candrawati S, Sulisttyoningrum E, Bramantyo A, Pranasari N. Senam aerobik meningkatkan daya tahan jantung paru dan fleksibilitas. J Kedokt Brawijaya. 2016;29(1):69-73.

7. Venantius. Perbedaan $\mathrm{VO}_{2}$ Max Siswa Kelas XI kelas Olahraga SMAN 1 Seyegan dengan Siswa Kelas XI Kelas Olahraga SMAN Ngaglik Kabupaten Sleman T.A 2015/2016. 2016;

8. Rosidah. . Perbedaan Pengaruh latihan Senam Aerobic Low Impact dan Mix Impact Terhadap Tingkat Kesegaran Jasmani pada siswa di SMK Negeri 1 Surakarta. J IKIP UNS [Internet]. 2012; Available from: Uns.ac.id/index.php/penjaskesrek/article/view/952

9. Sharma HB, Kailashiya J. Gender Difference in Aerobic Capacity and the Contribution by Body Composition and Haemoglobin Concentration: A Study in Young Indian National Hockey Players. J clin Diagn Res. 2016;10(11).

10. Anggraini A. Senam aerobik meningkatkan kelincahan. J Penelit Kesehat. 2016;4(1).

11. Tanziila R. Latihan Aerobik terhadap Kebugaran Kardiorespirasi pada Siswa SMP di Palembang. In: APKKM ke 6 Fakultas Kedokteran Universitas Muhamadyah Surabaya. Surabaya; 2018.

12. Richard T. Aerobic Instructur Manual: The resource for Fitness Profesional. Am Counc Exerc. 2009; 